\title{
DETERMINANTS OF CONSUMER PREFERENCE FOR PETROL CONSUMPTION: THE CASE OF PETROL RETAIL IN THE GAMBIA
}

\author{
MUSA MANNEH, MIKHAIL KOZHEVNIKOV \& TATYANA CHAZOVA \\ Department of Energy and Industrial Management Systems, Ural Federal University, Russia
}

\begin{abstract}
Service organizations in today's globalized competitive business environment engaged in marketing strategies are geared toward responding to consumer needs and preferences and, at the same time, improve their competitive edge. Investigating the determinants of consumer preference is one of the important approaches to improving competitive edge of petrol station business. Despite significant studies on consumer behavior, especially factors that affect a new brand or products, there is limited empirical investigation on the premise of determinants of consumer preference particularly in petrol station business, thus creating a gap in this area. To this effect, this article intends to contribute in filling the knowledge gap by investigating the determinants of consumer preference and their impact on service station business in the Gambia. This article also identifies key marketing strategies that petrol station business can use to increase their market share. Using non-probability convenience sampling, data were collected from 200 customers of petrol stations using self-administered questionnaires. Descriptive statistics, correlation and regression analysis were applied to analyze data using IBM SPSS statistics Version 22. The results of regression analysis identify marketing program and additional services out of the eight variables (marketing program, additional services, petrol station image, location, price, product assortment, service quality and management of service station) as the major determinants of service station consumer preference in the Gambia. This implies that petrol station companies should engage key marketing program strategies such as sales promotion, innovative product advertising, event sponsorship or association besides the provision of additional services like windscreen cleaning, water and air pumping, convenience store, fuel and motor product accessories sales plus services in order to increase sales as well as retain a large number of buyers as loyal customers.

Keywords: additional services, consumer preference, marketing programs, multiple regression analysis, petrol station, sustainable energy market.
\end{abstract}

\section{INTRODUCTION}

The 21st century business environment is dynamic, thus subjected to rapid changing circumstances, making it essential for businesses to redesign their activities in order to successfully deliver superior customer value. One key approach is understanding consumer behavior. The latter is broad and diverse but one of its newest dimensions is consumer preference. Investigating consumer preference will enable marketers to develop consumer choice influence strategies [1]. Also, in order for firms to be able to cope with these competitive business challenges, they should undertake various strategic measures aimed at providing a better quality price ratio (value for money) [2]. A study by Shimp and Andrews [3] shows that public relation is a fundamental part of a sales representative's job for the fact that a firm's activities involved strengthening goodwill between the company and the general public. In addition, Futrell [4] reported that companies build relationships by listening to their customers and arrange the company efforts to solve customer problems. According to Muruiki [5] and Kakunu [6], successful marketing of a company's product required measuring factors that influence consumer preference as well as laying emphasis on market segmentation through preferences and effective product positioning in the minds of consumers. 
Despite significant studies on consumer behavior especially factors that affect new branded products, there is limited empirical research conducted on the determinants of consumer preferences with regard to petrol station consumers. This situation leaves the field not fully explored although few studies conducted confirmed that there is a relationship between consumer preference and petrol station company selection. These studies recommend future researches to investigate the impact of consumer preferences on the internal and external business competitive strategies.

\subsection{Research problem}

In recent years, liberalization of service sector by the Gambian government shows transformation from a monopoly to open market competition. This implies that enterprises operating in retail petroleum sector are increasingly forced to pay attention to end users of their products. By extension, this phenomenon also witnesses an increasing number of petrol station companies who sell fuel and other petroleum products within the economy. To this effect, there is a growing challenge for marketing practitioners and academics concerning the increasing number of companies selling almost the same products, to the same customers.

Consequently, the authors are of the opinion that this subject needs further empirical studies in order to explore the determinants of consumer preference regarding petrol station service outlet selection. Therefore, this research seeks to bridge a literature gap by investigating the determinants of consumer preference for petrol consumption, in the case of petrol retail in the Gambia.

It is worth pointing out that this study is limited to determinants of individual consumer preference and its impact on downstream petroleum retail consumption sector from when refine petroleum products are imported into the country until they reach the final consumers. Thus, activities or practices pertaining to downstream organizational buyers plus upstream subsectors were not considered.

\section{THEORETICAL BACKGROUND}

According to Kontota et al. [7], consumer preference in marketing means the likelihood to choose one thing over another. This research explains that it is a process through which customers collect relevant information concerning the product attribute and evaluate the information according to their preference before assigning a value to choose between alternatives. In addition, preference is also viewed in psychology as an individual's attitude toward a set of objects that stimulates the person's behavior in the decision-making process [8]. Meanwhile, a study by Blackwell et al. [9] revealed that the theory of buyer behavior, the consumer decision model, the theory of reasoned action and the theory of planned behavior are among the four extensively cited models in consumer behavior. However, Bray [10] criticize these models' failure to address the role of ethics, social responsibility and philanthropy given in the intense rise of consumer behavior issues. Furthermore, the normative theory of decision making states that customers would evaluate the options before making a decision that maximizes the value of choice [11]. However, normative theory of 'Value Maximization' has been criticized heavily due to its ignorance of human limitation [12]. The bounded rationality theory by Simon [13] states that customers have limited search processing capability that ends once suitable solutions have been identified. Moreover, the Engel consumer model reports that consumer decision-making process comprises of defining problems, information 
search, evaluating alternatives, deciding on the options, implementing the decision and monitoring the solutions [14].

In economic perspective, consumer preference theory is a branch of microeconomics that studies consumer choice making behavior. This theory has four elements, namely income, price of goods, taste or preference, and behavioral assumption of 'utility maximization'. The derivatives of this theory give rise to many variables that are among the most critical factors shaping the overall determinants of consumer preference studied in applied economics today [15]. In economics, consumer preference is measured by the utility of various bundles of goods [16]. The study by Suresh and Keerthika [17] concluded that there is a significant relationship between consumer choice of fuel outlets and additional services offered in those retail outlets through a convenience store. Likewise, Kavitha and Sagaya [18] confirm that there is equally a relationship between customers' perceived service quality and their perception of petrol outlet choice. The result also indicates that demographic factors like age, gender and education have an association with customer's perceived services provision in the retail outlet.

Similarly, Kumari and Devi [19] discovered that there is a correlation between consumer behavior and supplementary services offered in the petrol station outlets. Still, Dutsenwai et al. [20] reported that service quality sales promotion and product assortment are important predictors of customer loyalty in Malaysian petrol stations. Furthermore, Srinivasan [21] revealed that petrol station's proximity to consumer's residence plus additional services such as air, water and parking facilities are the major determinants of consumer's preference. Moreover, the study in Ref. [22] shows that improved external appearance of the petrol station leads to the customer loyalty, thus building strong positive customer reaction.

Equally, the research of Saeed et al. [23] confirms significant positive relationship between customer satisfaction, trust and commitment with customer loyalty in Pakistan stations. On the other hand, Saini and Matinise [24] examine customer decision-making behavior using the Customer Styles Inventory model. The findings of this study provide empirical evidence indicating that fuel service providers should create shopping environments that are easily accessible and offer speedy service delivery.

However, the research result of Kakunu [6] shows that service quality fuel station overall image and additional service offering are the top determinants of petrol stations in Nairobi.

The above literature discussion confirms that retail petrol consumptions are shaped by certain determinants. As a result, this research identified and adopted constructs that the research deems fit for further investigation. These variables are as follows:

\subsection{Fuel station service quality}

According to Dutsenwai et al. [20], service quality is 'just the measuring of a particular service and also the understanding of the customer's expectation of what the service deliveries are'. According to Refs [15-18], service quality has the foremost strategic influence for service organizations that reflect the customer's perception of reliability, responsiveness, assurance, empathy and tangibility. In addition, service quality is an action or an activity, which can be offered by any organization tangible or intangible mostly through customer services with the use of technology in a competitive business environment [19-21]. Also, Saeed et al. [23] further revealed that service quality has clear relationships to costs, profitability, customer satisfaction, customer retention, behavioral intention and positive word of mouth plus productivity. Furthermore, it was reported $[6,23,24]$ that service quality is an 
important predictor of customer loyalty in petrol station outlets. To this effect, the construct of service quality needs to be further investigated in the premises of petrol station consumer preference.

\subsection{Fuel station overall image}

The authors of Refs [6] and [20] remark that perceptions of service entities' product can emerge through several image base associations and are key determinants of service organization's corporate image building. Studies presented in Refs [17, 18] recognize that ecological image of service stations is becoming increasingly important consideration for petrol station managers because it can ensure timely waste disposal as well as the use of the most efficient motor fuels. However, studies presented in Refs [23, 24] disagree with these findings. Therefore, there is the need for this research to examine this variable.

\subsection{Petrol station marketing programs}

According to the study in Ref. [6], petrol stations should create and conduct more advertisement and public relation campaigns in addition to sales promotion because it helps to attract more customers to the petrol stations. Similarly, Kumari and Devi [19] added that the execution of petrol stations' marketing programs through marketing mix elements helps to ensure repeated purchase and retain customers. This according to Saeed et al. [23] will help reduce customer switching behavior. Then, marketing program variable needs further empirical test to establish its existing or non-existing relationship with consumer preference.

\subsection{Product assortment}

Many studies conducted in recent years conclude that [20,23] it is important for today's businesses to offer a wide range of products because it will give consumers a better choice for making a decision and may possibly reduce their switching intention. Meanwhile, Srinivasan [21] revealed that a wide range of products may lead to superior positive satisfaction, hence the need to further investigate this variable to determine its significance as well as impact on the consumer preference of retail petrol station.

\subsection{Location of the petrol (fuel) station}

Kanuku [6] describes business location as an important brand feature for consumer purchasing decision. Furthermore, the empirical study in Ref. [20] mentions that location has significantly helped motor fuel retailers to achieve high performance. Similarly, the empirical study conducted on the fuel retailing industry of South Africa [24] discovered that if all other factors are constant, location becomes the most important determinant factor influencing consumer decision making, thus the need to further investigate this hypothesis statement.

\subsection{Additional services}

The literature review of this empirical research revealed that the offering of additional services by petrol stations helps to retain the existing and attract new customers as well enhance 
customer satisfaction plus loyalty building through preference choice making [6, 21, 23], hence the need to further test this variable in order to answer this hypothesis claim.

\subsection{Price}

According to the research in Refs $[6,19]$, price comprises both monetary and non-monetary value of a product, i.e. tangible and intangible cost. Kavitha and Sagaya [18] added that price is not only a marketing mix element but also a revenue generating arm for the business entity and thus price is the topmost important variable that customers/consumers consider during the purchase process [17]. Meanwhile, the study in Ref. [24] revealed that consumers of petrol station products are price conscious in the sense that they want to get a balance between paying for a low priced fuel and value for money. To this effect, these researchers deem it prudent to investigate and establish if there is any significant relationship between consumer preference and price.

\subsection{Management of the service station}

From this literature discussion, one can see that service quality and management of service station are very close but what type and magnitude of relationship exist between them and consumer preference is not mentioned in the literature [6, 24]. In addition, there is no discussion of any previous findings on the premise of determinants of consumer preference with management of service station as a construct other than in Ref. [6], hence the reason for including this variable in this study.

\section{METHODOLOGY}

The aim of this research analysis was to investigate the determinants of consumer preference of the petrol stations in the Gambia. The respondents are individual petrol consumers. The study employs a convenience sampling that is a non-probability sampling technique where respondents are selected based on their availability, accessibility, willingness and proximity to participate in the study.

A sample size of 200 respondents was used in the survey. However, 180 questionnaires were filled accurately and returned while 20 were not useful. A Pearson correlation analysis was used to examine the direction, strength and significance of the variables' relationships as well as multiple regressions. SPSS version 22 was used to analyze the data. The study was entirely conducted in English language and all the questions of the constructs were obtained from previous literature sources. The scale items in all constructs are at least three (3) questions as recommended by most researchers.

\subsection{Hypothesis statement}

Based on the above scientific literature review, eight hypothesis statements were adopted to further test the validity and reliability of the constructs. The summary of the hypothesis statements adopted for this study and the test results are presented in Table 1, which shows that four out of the eight construct variables (marketing programs, additional services, petrol station overall image/brand and location) were statistically significant with consumer preference (i.e. $\mathrm{p}<0.05$ ), thereby allowing us to confirm the hypotheses. Meanwhile, 
Table 1: Summary of the result of hypothesis test.

\begin{tabular}{|c|c|c|}
\hline Hypotheses & $\begin{array}{l}\text { Values } \\
\text { scored }\end{array}$ & $\begin{array}{l}\text { Determina- } \\
\text { tion }\end{array}$ \\
\hline $\begin{array}{l}\mathbf{H}_{1} \text { : The service quality of petrol station outlets/companies } \\
\text { will influence consumer preference of petrol consumption. }\end{array}$ & $\begin{array}{l}r=0.131 \\
p=0.079 \\
(p>0.05)\end{array}$ & $\begin{array}{l}\text { Not sup- } \\
\text { ported }\end{array}$ \\
\hline $\begin{array}{l}\mathbf{H}_{2}: \text { The overall image of petrol station outlets/companies } \\
\text { will influence consumer preference of petrol consumption. }\end{array}$ & $\begin{array}{l}r=0.258 \\
p=0.000 \\
(p<0.05)\end{array}$ & Supported \\
\hline $\begin{array}{l}\mathbf{H}_{3}: \text { The marketing programs of petrol station outlets/compa- } \\
\text { nies will influence consumer preference of petrol consump- } \\
\text { tion. }\end{array}$ & $\begin{array}{l}r=0.461 \\
p=0.000 \\
(p<0.05)\end{array}$ & Supported \\
\hline $\begin{array}{l}\mathbf{H}_{4}: \text { The product assortment of petrol station outlets/compa- } \\
\text { nies will influence consumer preference of petrol consump- } \\
\text { tion. }\end{array}$ & $\begin{array}{l}r=0.130 \\
p=0.081 \\
(p>0.05)\end{array}$ & $\begin{array}{l}\text { Not } \\
\text { supported }\end{array}$ \\
\hline $\begin{array}{l}\mathbf{H}_{5}: \text { The location of petrol station outlets/companies will } \\
\text { influence consumer preference of petrol consumption. }\end{array}$ & $\begin{array}{l}r=0.198 \\
p=0.008 \\
(p<0.05)\end{array}$ & Supported \\
\hline $\begin{array}{l}\mathbf{H}_{6} \text { : The additional services offered by the petrol station out- } \\
\text { lets/companies will influence consumer preference of petrol } \\
\text { consumption. }\end{array}$ & $\begin{array}{l}r=0.360 \\
p=0.000 \\
(p<0.05)\end{array}$ & Supported \\
\hline $\begin{array}{l}\mathbf{H}_{7}: \text { The price of fuel and other services offered by the petrol } \\
\text { station outlets/companies will influence consumer preference } \\
\text { of petrol consumption. }\end{array}$ & $\begin{array}{l}r=0.143 \\
p=0.056 \\
(p>0.05)\end{array}$ & $\begin{array}{l}\text { Not } \\
\text { supported }\end{array}$ \\
\hline $\begin{array}{l}\mathbf{H}_{\mathbf{8}} \text { : The management of the service stations of the petrol sta- } \\
\text { tion outlets/companies will influence consumer preference of } \\
\text { petrol consumption. }\end{array}$ & $\begin{array}{l}r=0.052 \\
p=0.486 \\
(p>0.05)\end{array}$ & $\begin{array}{l}\text { Not } \\
\text { supported }\end{array}$ \\
\hline
\end{tabular}

constructs of service quality, product assortment, price and management of petrol station service outlet all show an insignificant relationship with consumer preference (i.e. $\mathrm{p}>0.05)$. Hence this shows that there is no statistical significance and consequently these variables do not influence consumer preference as far as Gambia's petrol consumers are concerned.

\subsection{Reliability test}

A reliability test is quite imperative for the researchers to assess the relevance of the item scales used in this study. A Cronbach's alpha reliability score for service quality (0.762), image (0.831), marketing programs $(0.938)$, product assortment $(0.811)$, location $(0.853)$, additional services $(0.867)$, price $(0.706)$ and management of service station $(0.765)$ are obtained from the study. The results of the test are also listed in Table 2.

The reliability and internal consistency test of the constructs in the previous studies is summarized in Table 3. 
Table 2: Cronbach's alpha values.

\begin{tabular}{lcc}
\hline Scale name & Number of items & Cronbach's alpha value \\
\hline Service quality & 3 & 0.762 \\
Image & 3 & 0.831 \\
Marketing programs & 3 & 0.938 \\
Product assortment & 3 & 0.811 \\
Location & 3 & 0.853 \\
Additional services & 3 & 0.867 \\
Price & 3 & 0.706 \\
Management of service station & 4 & 0.765 \\
\hline
\end{tabular}

Table 3: Origin of constructs from previous literature.

\begin{tabular}{|c|c|c|}
\hline Scale name & $\begin{array}{l}\text { Cronbach's } \\
\text { alpha value }\end{array}$ & Scale source \\
\hline Service quality & 0.771 & Dutsenwai et al. [20] \\
\hline Image & 0.778 & Kakunu [6] \\
\hline $\begin{array}{l}\text { Marketing } \\
\text { programs }\end{array}$ & 0.791 & Kakunu [6] \\
\hline $\begin{array}{l}\text { Product } \\
\text { assortment }\end{array}$ & 0.775 & Dutsenwai et al. [20] \\
\hline Location & 0.780 & Dutsenwai et al. [20] \\
\hline $\begin{array}{l}\text { Additional } \\
\text { services }\end{array}$ & 0.780 & Kakunu [6] \\
\hline Price & 0.752 & Saini and Matinise [24] \\
\hline $\begin{array}{l}\text { Management of } \\
\text { service station }\end{array}$ & 0.759 & Kakunu [6] \\
\hline
\end{tabular}

\section{RESULTS AND DISCUSSION}

To analyze the relationship between service quality, image, marketing programs, product assortment, location, additional services, price and management of service stations, a Pearson correlation analysis is used to assess the magnitude of linear association between two variables. The results of this analysis are listed in Table 4, which shows that the correlation coefficient of all the constructs tested did not exceed 0.74, which means that the constructs are disperse and do not overlap with each other. The result also shows that four (image, marketing programs, location and additional services) out of the eight independent variables are strongly correlated with the dependent variable - consumer preference as indicated by $\left.{ }^{(* *}\right)$ in Table 4.

In addition to a Pearson's correlation analysis, a multiple regression analysis was conducted to further test the eight hypotheses identified for this study. The results of this analysis 
Table 4: Correlation summary of the determinants of consumer preference.

\begin{tabular}{lll}
\hline Constructs & Statistics & Consumer preference \\
\hline Service quality & Correlation & 0.131 \\
& Sig. (two-tailed) & 0.079 \\
Image & Correlation & $0.258^{* *}$ \\
& Sig. (two-tailed) & 0.000 \\
Marketing programs & Correlation & $0.461^{* *}$ \\
\multirow{3}{*}{ Product assortment } & Sig. (two-tailed) & 0.000 \\
& Correlation & 0.130 \\
Location & Sig. (two-tailed) & 0.081 \\
\multirow{2}{*}{ Additional services } & Correlation & $0.198^{* *}$ \\
Price & Sig. (two-tailed) & 0.008 \\
& Correlation & $0.360^{* *}$ \\
Management of service station & Sig. (two-tailed) & 0.000 \\
& Correlation & 0.143 \\
& Sig. (two-tailed) & 0.056 \\
\hline
\end{tabular}

are presented in Tables 5 and 6 . The results show that marketing program and additional services are the two most determinant variables of petrol consumption in the Gambia. These two independent predicting variables are shown in the stepwise regression model of Table 6 by superscript $\boldsymbol{a}$ for marketing programs and $\boldsymbol{b}$ for additional services while the dependent variable is indicated by superscript $\boldsymbol{d}$.

Furthermore, the stepwise regression model summary shows that marketing program and additional services are the two most determinant variables of petrol consumption in the Gambia. Marketing program has a standardized regression coefficient $\beta$ value of 0.461 , which was the highest among the two predicting variables. This indicates that Gambia's petrol station

Table 5: Stepwise multiple regression analysis.

\begin{tabular}{|c|c|c|c|c|c|c|c|}
\hline & \multirow[t]{2}{*}{ Model } & \multicolumn{2}{|c|}{$\begin{array}{l}\text { Unstandardized } \\
\text { coefficients }\end{array}$} & \multicolumn{2}{|c|}{$\begin{array}{l}\text { Standardized } \\
\text { coefficients }\end{array}$} & \multirow[t]{2}{*}{$\mathbf{T}$} & \multirow[t]{2}{*}{ Sig. } \\
\hline & & B & Std. error & Beta & & & \\
\hline \multirow[b]{2}{*}{1} & (Constant) & 2.465 & & 0.366 & & 6.742 & .000 \\
\hline & $\begin{array}{l}\text { Marketing } \\
\text { programs }\end{array}$ & 0.458 & & 0.066 & 0.461 & 6.927 & .000 \\
\hline \multirow{3}{*}{2} & (Constant) & 1.417 & & 0.475 & & 2.984 & .003 \\
\hline & $\begin{array}{l}\text { Marketing } \\
\text { programs }\end{array}$ & 0.380 & & 0.068 & 0.382 & 5.551 & .000 \\
\hline & $\begin{array}{l}\text { Additional } \\
\text { services }\end{array}$ & 0.247 & & 0.074 & 0.229 & 3.332 & .001 \\
\hline
\end{tabular}


Table 6: Stepwise regression strength of the relationship.

\begin{tabular}{lllll}
\hline & \multicolumn{4}{c}{ Model summary ${ }^{\text {d }}$ (stepwise method) } \\
Model & $\mathbf{R}$ & $\mathbf{R}^{\mathbf{2}}$ & Adjusted $\mathbf{R}^{\mathbf{2}}$ & Std. error of estimate \\
\hline 1 & $0.461^{\mathrm{a}}$ & 0.212 & 0.208 & 1.00351 \\
2 & $0.509^{\mathrm{b}}$ & 0.259 & 0.250 & 0.97619 \\
\hline
\end{tabular}

consumers value marketing program of petrol stations over the rest of the independent variables. Additional service offering is the second influential factor of petrol consumption, with a standardized coefficient $\beta$ value of 0.382 . This research finding is consistent with previous findings in Refs $[6,17-19,21]$ where the authors stressed the significance of marketing programs and that innovative revenue generation through additional service offering determine consumer retail petrol consumption.

Also, the research findings in Refs $[6,20,24]$ all share similar conclusions with this study. Meanwhile, variables like petrol station's overall image and location also have a close relationship with consumer preference. In addition, the highest adjusted $\mathrm{R}^{2}$ value recorded was 0.259 , which indicates that this research variable only explains $25 \%$ of the determinants of consumer preference for petrol consumption in the Gambia. This seems to be on the low side, but researchers believe that when studies are conducted for the first time in a particular environment, the unfamiliarity of the respondents with the variables can produce such a result [25].

Consequently, the constructs of service quality, price, product assortment and service station management do not have an influence on consumer preference. The authors believe this is due to certain prevailing circumstances in the petrol retail industry. Firstly, this is the first time such an empirical research is carried out within the petrol retail industry in the Gambia; so, the customers and respondents are not used to these particular variables in this research. Secondly, retail petrol companies and their outlets are currently facing competition in terms of product or brand assortment selling of petroleum products. Local vendors are now selling many fuel-related products such as engine oils, oil filters, tires just to name a few at strategic point of purchase locations near petrol station outlets. To this effect, retail petrol consumers do not attach significance to wide product assortment offering in petrol stations in the Gambia. Besides, the fuel prices in the Gambia do not change with the world market circumstances but changes with government decisions and policies. The fuel prices in the Gambia are set up by the Government through the Ministry of Finance and Economic Affairs. Moreover, for the past two decades, the Government of the Gambia always sets up fuel prices above the world market price because the difference in price revenue is used for funding national budget deficit. Thus, petrol station companies/outlets do not have price variance; thus, this is of no significance to consumers.

\section{CONCLUSION}

The results of this study revealed that marketing programs and additional services are critical factors that significantly influence retail petrol consumption in the Gambia. Other factors such as petrol stations overall image, service quality and location, too, have a close relationship with consumer preference. In light of this, downstream retail petrol station companies need to develop robust strategic marketing programs, strong innovative related and unrelated additional services, and superior service quality delivery at strategic petrol station outlets. 


\subsection{Recommendations}

Petrol stations should employ marketing strategies such as sales promotion, innovative product advertising and event sponsorship in attracting more customers. Also petrol stations should provide additional services like windscreen cleaning, water and air pumping, ATM services, pharmacy outlets, convenience stores, and offer fuel and motor accessories and related services (e.g. engine and oil filters, tires, etc.), in order to give customers the opportunity of buying a wide range of products in addition to the petroleum products. Furthermore, petrol stations should equally adopt and implement strategic outlet locations and promotional activities geared toward company superior product quality delivery assurance, image or brand building. This will help to increase customer loyalty as well as reduce the switching behavior of customers.

\subsection{Research contribution}

This study is the first research that examines the determinants of consumer preference for petrol consumption in the Gambia. Therefore, the study will benefit future researchers by establishing a knowledge base in petrol station consumer preference. In the Gambia, most of the oil and petroleum industry income comes from the downstream sector, so as a pioneer research of the sector, its findings will not only benefit the entire industry as a whole but also the sector in particular in terms of acquiring new business development and competitive strategies.

\subsection{Limitation and suggestion for future research}

The study used a convenience sample rather than a random sample, i.e. the study adopts non-probability sampling instead of probability sampling. Therefore, future studies should use probability sampling like random or stratified sampling in order to generalize results obtained to a larger population.

Secondly, future studies should employ longitudinal survey rather than cross-sectional survey, because in cross-sectional survey, data are collected at a single point of time from multiple cases, but the issues of causality are not considered; so, future studies should use longitudinal survey in which the researchers will administer a survey to one set of respondents over multiple time points and issues of causality can be determined.

Additionally, the survey used a quantitative method that is based on questionnaires. One key benefit of using questionnaires or quantitative analysis is that hypotheses can be directly tested based on the empirical data collected from questionnaires. However, future studies should incorporate qualitative analysis that will further explore aspects of this research. In-depth interviews utilizing open-ended questions could allow for deeper exploration of these measures. Future researches should also focus on other group of respondents and lastly, compare the different petrol station companies in Gambia.

\section{ACKNOWLEDGEMENT}

The work was supported by Act 211 of the Government of the Russian Federation, contract № 02.A03.21.0006.

\section{REFERENCES}

[1] Liu, Z., Feng, J. \& Liu, B., Pricing and service level decisions under a sharing product and consumers' variety-seeking behavior. Sustainability, 11(24), 6951, 2019. https:// doi.org/10.3390/su11246951 
[2] Randall, G., Trade Marketing Strategies: the Partnership between Manufacturers, Brands and Retailers, Butterworth-Heinemann: Oxford, 1994. 183 p.

[3] Shimp, T.A. \& Andrews J.C., Advertising, Promotion \& Supplemental Aspects of Integrated Marketing Communications, Cengage Learning: South-Western, 2013. 729 p.

[4] Futrell, C.M., Fundamentals of Selling: Customers for Life through Service. McGrawHill: New York, 2014. 672 p.

[5] Muruiki, J.W., A Survey of Factors that Determine Architects Preference for Roofing Materials in Nairobi, MBA Project, University of Nairobi, 2003, http://erepository. uonbi.ac.ke/handle/11295/22937. Accessed on: 07 Feb. 2020.

[6] Kakunu, J.K., Determinants of Consumer Preference in Choice of Petroleum Service Outlets in Nairobi, MBA Project, University of Nairobi, 2012, http://erepository. uonbi.ac.ke/bitstream/handle/11295/13610/AULIUS_LEORNARD_MUSYOKA_ MBA_2012.pdf?sequence=3\&isAllowed=y. Accessed on: 07 Feb. 2020.

[7] Kontota, K., Hamalib, J., Abdullah, F., Determining factors of customers' preferences: a case of deposit products in Islamic banking. Procedia - Social and Behavioral Sciences, 224, pp. 167-175, 2016. https://doi.org/10.1016/j.sbspro.2016.05.435

[8] Lichtenstein, S. \& Slovic, P. (eds), The Construction of Preference, Cambridge University Press: Cambridge, 2006.

[9] Blackwell, R.D., Miniard, P.W. \& Engel, J.F., Consumer Behavior, Harcourt College Publishers: London, 2001.

[10] Bray, J.P., Consumer Behaviour Theory: Approaches and Models. Discussion Paper, http:// eprints.bournemouth.ac.uk/10107/1/Consumer_Behaviour_Theory_-_Approaches_\%26_ Models.pdf. Accessed on: 07 Feb. 2020.

[11] Lau, R.R., Information search during an election campaign: introducing a process tracing methodology to political science. Political Judgment: Structure and Process, eds. M. Lodge \& K. McGraw, University of Michigan Press: Ann Arbor, pp. 179-205, 1995.

[12] Moorthy, S., Ratchford, B.T., \& Talukdar, D., Consumer information search revisited: theory and empirical analysis. Journal of Consumer Research, 23(4), pp. 263-277, 1997. https://doi.org/10.1086/209482

[13] Simon, H.A., Human nature in politics: the dialogue of psychology with political science. The American Political Science Review, 79(2), pp. 293-304, 1985. https://doi. org/10.2307/1956650

[14] Engel, J.F., Blackwell, R.D., \& Miniard, P.W., Consumer Behavior, International edition, Dryden: Florida, 1995.

[15] Thiyagaraj, V., A study of consumer preference towards branded tea in Tiruppur City. Global Journal for Research Analysis, 4(5), pp. 207-208, 2015.

[16] Sowunmi, F.A., Omigie, O.C., \& Daniel, D.T., Consumers' perception on Ofada rice in Ibadan North local government area of Oyo State, Nigeria. Journal of Economics and Sustainable Development, 5(16), pp. 78-86, 2014.

[17] Suresh, A. \& Keerthika, R., An empirical study on impact of services provided by petroleum retail chains over retaining the loyalty of customers - Chennai Arena, India. Journal of Energy and Economic Development, 4(1), pp. 1-10, 2019.

[18] Kavitha, G. \& Sagaya A.M.J., A study on customer perception towards service quality of retail petrol outlets. EPRA International Journal of Economic and Business Review, 6(7), pp. 11-16, 2018. https://doi.org/10.36713/epra2980

[19] Kumari, R.K., \& Devi N.Y., A study on consumer behavior towards retail petrol outlet services in Coimbatore city. International Journal of Applied Research, 2(2), pp. 670-673, 2016. 
[20] Dutsenwai, H.S., Abdullah, A., Sedek, A.B., Jamak, A. \& Noor, A.M., Factors influencing customer loyalty in Malaysian petrol stations: moderating effect location. Journal of Scientific Research and Development, 2(12), pp. 56-63, 2015.

[21] Srinivasan, T., A study on consumer preferences of petroleum retail outlets. IOSR Journal of Business and Management, 17(2), pp. 35-40, 2015.

[22] Nderitu, D.M. \& Njuguna, R.K., The influence of retail network expansion on the competitive advantage of oil marketing firms in Kenya: case of Vivo Energy. International Journal of Sales, Retailing and Marketing, 6(2), pp. 3-16, 2017.

[23] Saeed, R., Rehman, A.U., Akhtar, N. \& Abbas, M., Impact of customer satisfaction and trust on customer loyalty mediating role of commitment (evidence from petroleum sector of Pakistan). Journal of Basic and Applied Scientific Research, 4(2), pp. 214-221, 2014.

[24] Saini, Y.K. \& Matinise, S.V., An exploratory study on factors influencing customer decision making: a case of fuel retailing industry in South Africa, https://pdfs.semanticscholar.org/e793/b2bfaedb2490f901095ba73ebcaac2054421.pdf. Accessed on: 07 Feb. 2020.

[25] Bagraim, J.J. \& Gird, A., The theory of planned behaviour as predictor of entrepreneurial intent amongst final-year university students. South African Journal of Psychology, 38(4), pp. 711-724, 2008. 